\title{
THE STATE OF TRAINING HIGHLY QUALIFIED PERSONNEL IN THE FIELD OF TOURISM, ANALISY THERE PROBLEM AND SOLUTION
} (On the example of the Republic of Uzbekistan)

\author{
A.I. Rakhmatov \\ Base Doctoral Student, Samarkand institute of economics and service
}

Article DOI: https://doi.org/10.36713/epra5903

\begin{abstract}
In the article, the researcher describes the level and status of higher education in the tourism industry of the Republic of Uzbekistan, the scientific and theoretical approaches to the problems and offers to further develop the system of training and retraining of qualified personnel (in higher education). quoted

KEY WORDS: tourism, specialist, tourist, domestic tourism, modernization, guide, manager, tour operator,education, training, retraining quality, personnel.
\end{abstract}

\section{DISCUSSION}

According to the World Tourism Organization (WTO), this year's results compared to 2019 have led to a $98 \%$ reduction in the number of international tourists due to the disruption of the COVID-19 pandemic, resulting in a decline in international tourism revenues between January and May 2020 released As a result of the reduction in the number of international tourists by 300 million, international tourism revenues fell by $\$$ 320 billion. The result of this loss is three times that of the 2009 global financial and economic crisis. Currently, 90 countries are fully or partially closed to tourists; 209 routes, i.e. $96 \%$ of all routes in the world are restricted; the tourism industry could suffer $\$ 22$ billion in damage. WTO Secretary General Zurab Pololikashvili noted that no event in history has yet affected tourism and tourism like COVID-19. Countries have made travel a priority, with health as a priority. However, the cessation of tourism has created a chain reaction, leading to a sharp reduction in jobs, which in turn undermines sustainable economic growth.In particular, the tourism industry could cut about 50 million jobs. Of this, $30 \mathrm{mln}$. Asia, $7 \mathrm{mln}$. Europe, $5 \mathrm{mln}$. It applies to America and the rest of the region. The Asian region is considered to be the most affected continent. Tourism accounts for $10 \%$ of world GDP. Therefore, the WTO constantly calls on governments to reconsider the restrictions and mitigate some areas as much as possible. One of the most pressing issues is the introduction of curricula in our education system, the solution of problems related to certification and the rational use of foreign education priorities.

During the years of independence, a new legal and economic framework for tourism based on market relations has been created in our country. Modern infrastructure facilities have been built and new world-class tourist destinations have been introduced. Along with the restoration of existing historical and cultural monuments, they were widely promoted. Such systemic measures are yielding the expected results, and the tourism potential of our country is growing. An example of this is a recent article in the world-famous British newspaper Financial Timis. It published a list of the most interesting destinations for those who want to travel around the world in 2017. Among the nine countries mentioned in the newspaper, Uzbekistan is ranked second in the ranking of the most attractive tourist destinations in the world. This is not in vain, of course. After all, Uzbekistan is one of the leading countries in the world in terms of tourism and the number of historical sites. The presence of more than 7,000 rare historical monuments and unique architectural samples in our country, the functioning of beautiful nature reserves, the preservation of centuries-old traditions of national culture, arts and crafts further 
strengthen the interest of foreigners in our country. However, due to the lack of rational use of existing opportunities, the industry's contribution to services and exports, its role in employment lags far behind the world average. Speaking at an enlarged meeting of the Cabinet of Ministers on the main results of socio-economic development of the country in 2016 and the most important priorities of the economic program for 2017 , the head of state said that the development of lucrative industries such as tourism is neglected. stressed the need to take concrete measures to promote our cultural values, as well as to replenish foreign exchange reserves. The analysis of the number of citizens arriving in the Republic of Uzbekistan from foreign countries shows that the number of foreigners visiting the country has increased 2.3 times over the past two years. For example, in 2017, the figure was 2.8 million, and in 2018 it was 6.4 million.

It is known that today world tourism occupies one of the highest incomes in the economy, provides employment for a large part of the working population, high socio-economic development, and in this regard, it has always had sustainable development. In the rapidly developing countries of the tourism industry, special attention is paid, first of all, to the services of high-class specialists who drive this industry. In particular, at the beginning of the 2018-2019 academic year, 360.2 thousand students are studying in higher education institutions, of which 159.4 thousand are girls. $22.1 \%$ of students study on the basis of state grants, $77.9 \%$ on a fee-for-service basis. The role of the staff working in the organization of tourism services is invaluable. In the field of tourism, it is very important to choose the right staff who meet the requirements of customers. Many employees interact directly with customers and are automatically involved in the process of achieving the organization's core goals, and the quality of service depends not only on their skills but also their level of awareness. Customer satisfaction in the field of tourism can also be achieved through the kindness and enthusiasm of the staff. The effectiveness of the company's work in the field of tourism depends on its staffing and the relationship between them. The need for well-trained staff with experience in the tourism industry and the high level of labor dissatisfaction determine the relevance of prudent personnel planning. In recent years, personnel planning has become as important as other economic resource planning in the enterprise management process. Therefore, personnel planning should be considered as an integral part of strategic planning. Since personnel planning is related to the overall development of a company, it must take into account changes in external factors, such as demographic changes, changes in the level of education and competition, as well as government intervention in the economy and the level of technological development.

The future of any country largely depends on the intellectual potential, skills and professionalism of national personnel, their competence, ability to forecast situations and adequately assess the economic situation, as well as how timely effective management solutions are adopted and implemented in practice. According to the state educational standard, students have the ability to apply in-depth general scientific knowledge, practical solutions to a wide range of economic and social problems in the enterprise, region, country, to act independently in various dynamically developing practical situations. the formation of the skills and readiness to make rational decisions is the goal of teaching them in economics.

The issue of training, retraining and advanced training of personnel for the tourism industry is also included in the main directions of state policy. Accordingly, the organization and development of scientific support in the field of tourism, as defined in Article 4 of the Law of the Republic of Uzbekistan "On Tourism"; The issues of training, retraining and advanced training are one of the main directions of state policy in the field of tourism.

From the first years of independence, measures to develop tourism in the country have been consistently implemented. In accordance with the Decree of the President of the Republic of Uzbekistan dated July 27, 1992, the National Company "Uzbektourism" was established. It is important that over the past period, a solid regulatory framework for tourism has been created. In particular, the Law "On Tourism" adopted in 1999 is one of the main documents regulating relations in the field of tourism.

The development of tourism in our country has been considered a priority of the state policy since the early days of independence. In particular, the Decree of the President of the Republic of Uzbekistan dated December 2, 2016 No PF-4861 "On measures to ensure the accelerated development of tourism in the Republic of Uzbekistan", December 2, 2016 No PP-2666 "On the organization of the State Committee for Tourism Development of the Republic of Uzbekistan" Resolution of the Cabinet of Ministers of January 26, 2017 No. 38 "On the program of additional measures for socio-economic development of the Samarkand region, further improvement of living standards", March 15, 2017 No. 137 "On further development of tourism in the Republic of Uzbekistan" on support and development measures ", June 30, 2017 
Resolution No. 450 "On measures to accelerate the development of tourism potential of Samarkand and Samarkand region in 2017-2019" was adopted. Decree of the President of the Republic of Uzbekistan Sh.M.Mirziyoev No. PF5326 of February 3, 2018 "On additional organizational measures to create favorable conditions for the development of tourism potential of the Republic of Uzbekistan", February 6, 2018 "On favorable organizational conditions for the development of tourism potential of the Republic of Uzbekistan" Resolutions No. PP-3509 "On additional organizational measures to create conditions" and PQ-3510 "On measures to further improve the activities of the State Property Committee of the Republic of Uzbekistan on the development of tourism", February 7, 2018 "On measures to accelerate the development of domestic tourism." These include Resolution No. PQ-3514 of January 5, 2019, Decree No. PF-5611 of January 5, 2019 "On Additional Measures for the Accelerated Development of Tourism in the Republic of Uzbekistan".

Indeed, tourism is an important component of the economy of many countries, which in turn serves as a factor in the employment of the local population, the loading of restaurants, hotels and the inflow of foreign currency into the local budget. Due to the domestic economic nature of tourism, the tourist must spend his money in the country where he travels, and it is natural for this country to receive its corresponding income as a result of tourism being based on the exploitation of local tourist resources. In this process, the training of modern qualified personnel for the tourism industry remains an urgent issue.

As stated in the "National Training Program", the introduction of innovative forms of education is required in order for the education system to adapt to high conditions of competition in market conditions, as in all sectors of the economy. These requirements apply directly to the training of personnel for the tourism industry, as well as all educational institutions. Today, modern tourism organizations and enterprises are a hightech service sector equipped with new information systems, computer technology and fluent foreign languages.

At present, the growth of innovative processes is considered a necessary element of the development and transformation of economic systems in the context of scientific and technological progress, as well as a key resource that provides a competitive advantage. At the same time, a modern specialist in the field of service can not continue his work without using the results of innovative processes, because the flow of scientific and technical information is growing rapidly, in which case a young specialist must be able to select technical innovations and innovative ideas and not without creative skills.

Timely attention of tourism enterprises to new technological changes in various areas of tourism-related activities, the ability to create new methods of work and improve performance are recognized as a prerequisite for the survival of enterprises. The need to introduce innovations also stimulates competition and a number of other market demands. Their usability is also related to changes in demographic, economic and social order due to changes in consumer demand and consumer desires, modern human psyche.

The golden rule of the service sector is the need to provide quality services to the customer, which remains the demand of the time. Qualified personnel in the field of tourism is playing a key role in the implementation of this problem.

At present, the main task of higher education institutions is to train highly qualified specialists with knowledge in the field of information and communication systems, who can effectively apply their new knowledge in practice, quickly adapt to the conditions of modernization of the service sector.

At the stage of modernization of the country, among the issues that need to be addressed in the field of tourism and hospitality industry, the training of personnel who can meet the qualification requirements for employees working in the labor market of the tourism industry remains an important issue. With this in mind, the Cabinet of Ministers of the Republic of Uzbekistan in accordance with the resolution "On the establishment of the Samarkand Institute of Economics and Service" set the Samarkand Institute of Economics and Service to train highly qualified specialists in priority areas of tourism. Currently, the school offers courses in "Tourism (by field of activity)", "Organization and management of hotel industry", "Tourism (by type of activity)", "Tourism and hotel services", "Marketing (tourism)", "Management ( tourism) », « Tourism marketing », « Tourism management », " Organization of tourism operator service », « Service (tourism and hotel industry) ».

In addition, the Faculty of International Tourism of Tashkent State University of Economics, Urgench, Bukhara, Karshi State Universities, Singapore Institute of Management Development in Tashkent, Samarkand Great Silk Road International Tourism University and a number of professional tourism colleges contribute to the training of qualified personnel in tourism. are added. 
Today, the training of qualified personnel for the tourism industry in the country is carried out in the following four stages:

1. Graduates of secondary specialized vocational colleges in the field of tourism work in the positions of ordinary employees, executors and mid-level employees of tourism enterprises.

2. Former students with bachelor's degrees in tourism are working as middle managers and heads of tourism enterprises.

3. Graduates of higher educational institutions in the field of tourism have the right to work as teachers of departments of universities, institutes and teachers of professional colleges, heads of tourist enterprises and general managers.

4. In-service training and retraining of staff working in the field of tourism in training centers and relevant courses.

Although there are currently more than two hundred professionals in the tourism industry, it is clear that the demand for various specialists in this field has not yet been fully met. We believe that it would be appropriate to explain this situation based on the results of research conducted by our scientists over the next six years.

For example, the results of a public opinion poll conducted to study the demand for tourism professionals in 28 tourism enterprises in Samarkand region show this. The demand for specialists in hotels and the demand for specialists in tourism companies are shown in Figures 1-2. ${ }^{1}$

\footnotetext{
${ }^{1}$ Amriddinova R.S. Mehnat resurslarini boshqarish asosida turizm xizmatlarining raqobatbardoshligini oshirish yo'llari (Samarqand viloyati turizm korxonalari misolida)"nomzodlik dissertatsiya. S.: SamISI, 2012.
} 


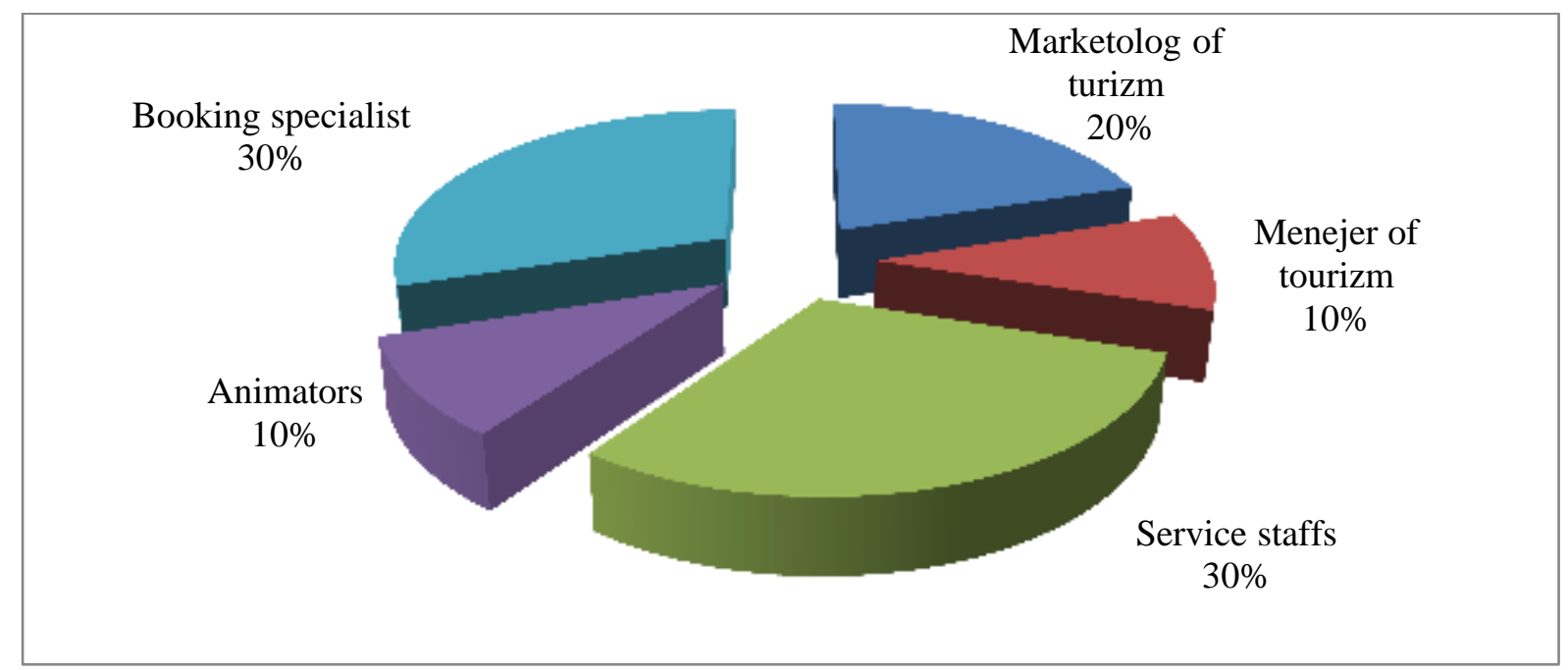

Figure 1. Demand for specialists in hotels in Samarkand region

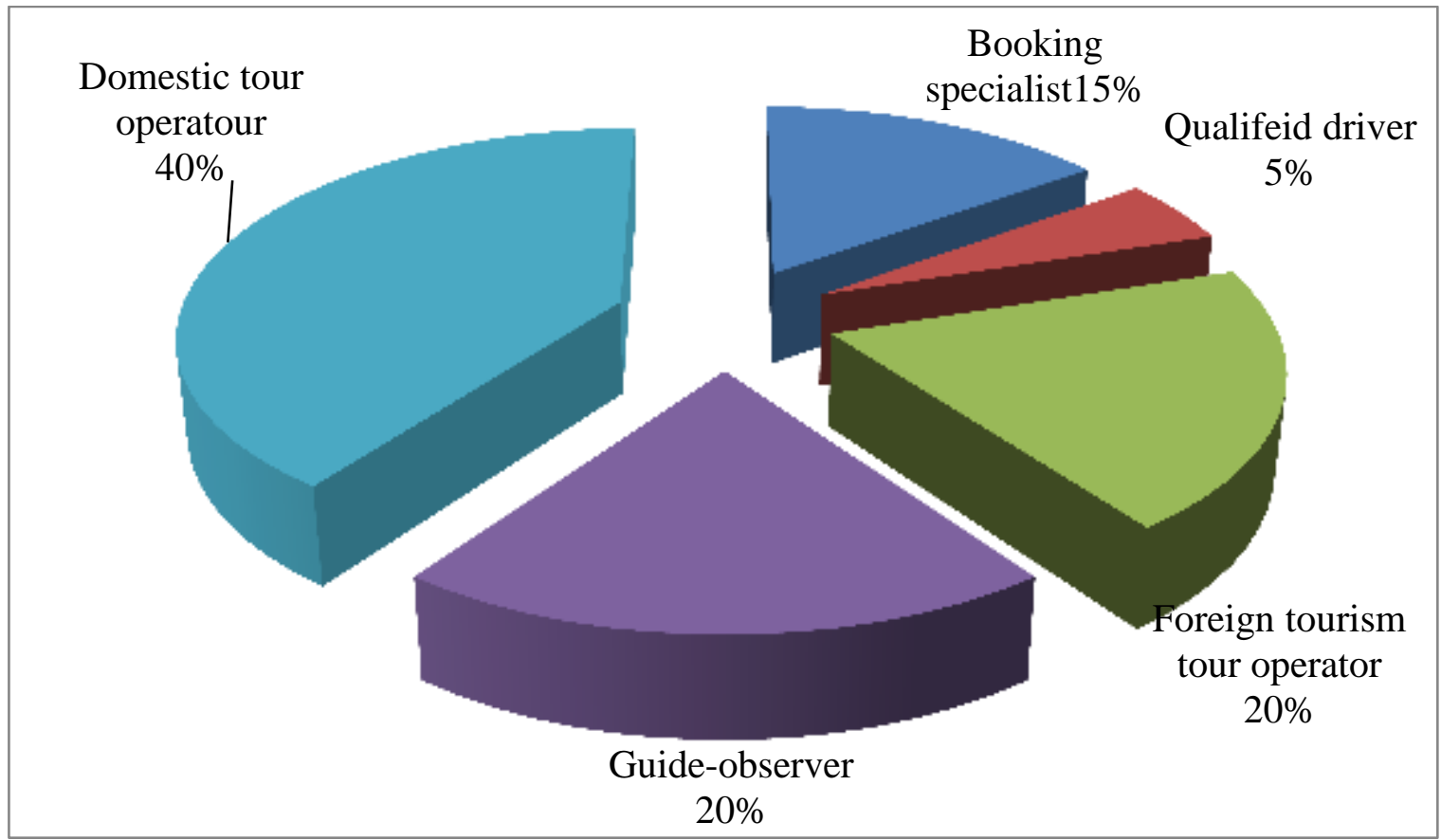

Figure 2. Demand for specialists in tourism companies in Samarkand region

We can conclude from the data in the pictures that now tourism enterprises are often trying to attract managers for domestic and foreign tourism, specialists who can work with automated ticketing systems, air tickets, railway tickets, hotels. Samarkand International Silk Road University of Tourism, Samarkand Institute of Economics and Service, as well as service staff (waiters, housewives, Swiss, etc.) Sartepo tourism and prepares a vocational college for domestic service. In addition, the development of modern Internet technologies requires employees in the field of tourism to be well versed in the field and use new booking systems, innovative technologies in their work, which in turn increases the demand for booking operators and managers.

Today, in order to increase the efficiency of training and retraining of tourism companies and hotel staff, there is an opportunity to organize the educational process on the basis of cooperation agreements with the Republican Scientific and Educational Consulting Center under the State Committee for Tourism Development and Samarkand Institute of Economics and Service.

This issue has been agreed with the Republican Scientific and Educational Consulting Center under the State Committee for Tourism Development of the Republic of Uzbekistan. The 
institute has all the conditions for the organization of training courses.

To do this, the regional government has to prepare a relevant decision of the Regional Council, which coordinates the development of tourism, to involve in these training courses for training and retraining of staff and managers of all existing hotels, catering, tourism enterprises and organizations in the region.

Even at a time when the coronavirus pandemic is on the rise around the world, the education system has not stopped. Each higher education institution has established distance learning using modern technological, innovative tools. In addition, research on international projects is not stopping, and more effective results are being achieved.

Samarkand International University of Tourism "Silk Road" is successfully working in this direction. Today, the university has won the right to participate in three prestigious international projects.

The program includes a program for 20182023 to establish international cooperation in the formation of creative entrepreneurial practices in order to develop the economies of UK educational institutions, universities and participating countries.

This program will undoubtedly make a significant contribution to the development of creative entrepreneurial skills in the educational process using the British experience. In the first year of the project, it is planned to attract more than ten thousand students and young entrepreneurs.

With the support of the US Embassy in Uzbekistan, a new project was launched in April 2020 in partnership with the Silk Road International Tourism University and the University of Wyoming. The project includes ESP seminars on tourism in English for teachers of Tashkent State University of Economics, Bukhara State University and the International University of Tourism "Silk Road" in Samarkand. This activity involves assessing teachers 'level of English proficiency.

Sustainable project Development of a special textbook for the tourism industry of Uzbekistan; teaching staff; organization of Englishlanguage student clubs on tourism; Silk Road International University of Tourism intends to develop online materials during the events (February 2020-June 2021).

In addition, the university's large-scale projects submitted to the Ministry of Innovative Development, aimed at studying the most important and topical issues in the field of tourism today, are also commendable. These are:

- Research project "Preservation of the New Silk Road Architectural and Cultural Heritage in the Age of Globalization" Russian International Academy of Tourism).
- Research project on "Creation of a smart technology package for pilgrimage tourism" to participate in the 12th competition under the grants of state scientific and technical projects in the field of informatization and information technology.

- Research project on "Creation of the Augmented Reality Based mobile application" ETrave Guide "to participate in the competition of scientific and technical projects in Uzbek-Indian cooperation.

- Research project on "Creation of an electronic platform" E-pilgrimage tourism "for participation in the 18th competition under the grants of state scientific and technical projects in history and social sciences."

- Research project on "Fundamentals of the spiritual struggle against destructive ideas based on the works of Central Asian thinkers" for participation in the 18th competition under the grants of state scientific and technical projects in history and social sciences.

Currently, the institute can organize the following courses in the field of tourism:

In retraining courses:

Managers, managers of

tourism enterprises and firms

Hotel administrators and

managers

Tour operators and travel agents, (computer technology with foreign language learning),

of travel agencies

Accountants, economists

In advanced training courses:

and cafe staff

Hotel and restaurant, bar

- Small and private hotel

maids

Bartender, waiter, wedding

waiters

Project estimates for the construction of a modern hotel complex on the basis of SamISI are being considered in order to integrate science, training and production, as well as the organization of student internships in the field of services and training.

In short, the system of training, retraining and advanced training in the field of tourism has been consistently established, which requires the elimination of shortcomings in this area and the continuous improvement of the system of training in the field of tourism. It is necessary to take into account the following in the process of training in this area:

Methodological support of interconnectedness and continuity of the educational process in lyceums, colleges and 
higher education institutions of the country; development and introduction of interactive teaching methods, modern information technologies;

Scientific

and

methodological support of the system of higher and secondary special, vocational education, the implementation of research aimed at training competitive personnel; Includes areas such as improving the organization of training of highly qualified personnel in the country on the basis of the study of advanced world experience.

Based on the requirements of the Action Strategy for socio-economic development of the Republic of Uzbekistan in 2017-2021, today it is necessary to address the following issues in order to further develop the system of training and retraining of qualified personnel serving the tourism sector:

- development of curricula and programs of education in cooperation with the employer;

- organization of training of tour operators and managers providing reservation services;

- In order to meet the high demand for guides and tour guides, and taking into account the fact that no higher education institution in the country prepares bachelors in these areas of education, to organize training in higher education institutions in the field of "guide and tour services";

- Establishment of a second specialization based on special courses or distance learning, aimed at bachelors trained in foreign languages in higher education institutions of the republic and employees with at least 3 years of experience in the field of tourism;

- In order to positively address the issue of training and retraining of employees working in the field of tourism, it is expedient to open branches of the Republican Scientific-Educational Consulting Center of Uzbektourism under the higher education institutions that train tourism specialists;

- Establishment of Cooperation Councils with employers at higher education institutions in order to positively address the issue of employment of graduates.

\section{LIST OF REFERENCES}

\section{Laws of the Republic of Uzbekistan}

1.1. Law of the Republic of Uzbekistan "On Tourism". - T., August 20, 2016.

II. Decrees of the President of the Republic of Uzbekistan and decisions

2.1. Decree of the President of the Republic of Uzbekistan dated December 2, 2016 No PF-4861 "On measures to ensure the accelerated development of tourism in the Republic of Uzbekistan."

2.2. Resolution of the President of the Republic of
Uzbekistan dated December 2, 2016 No PP-2666 "On the organization of the State Committee for Tourism Development of the Republic of Uzbekistan."

2.3. Decree of the President of the Republic of Uzbekistan No. PF-4947 of February 7, 2017 "On the Strategy of Actions for the Further Development of the Republic of Uzbekistan".

2.4. Resolution of the President of the Republic of Uzbekistan dated April 20, 2017 No PP-2909 "On measures to further develop the system of higher education."

2.5. Resolution of the President of the Republic of Uzbekistan dated July 12, 2017 No PP-3129 "On measures to further increase the responsibility of local executive authorities in the development of tourism."

2.6. Resolution of the President of the Republic of Uzbekistan dated August 16, 2017 No PP-3217 "On priority measures for the development of tourism in 20182019."

2.7. Resolution of the President of the Republic of Uzbekistan dated July 27, 2017 No PP-3151 "On measures to further expand the participation of industries and sectors of the economy in improving the quality of higher education."

2.8. Resolution of the President of the Republic of Uzbekistan dated January 5, 2019 No PP-4095 "On measures to accelerate the development of the tourism industry"

\section{Textbooks, monographs, textbooks} and manuals

3.1.Boltabaev M.R, Tuxliev I.S. and . Tourism: theory and practice. Textbook. T .. Science and Technology $2018 y$.

3.2.Mamatqulov X.M. Tourism infrastructure. Study guide. - S .: SamISI, 2020.

Socio-economic situation of the Republic of Uzbekistan - Statistical Bulletin, State Statistics Committee, Tashkent-2019,

\section{WEBSITES}

4.1.www.gdnet.org

4.2. www.stat.uz

4.3.www.lex.uz

4.4.www.uzbektourism.uz 